\title{
Gut Analysis of Broiler Chicken (Gallus domesticus) Feeding on Black Soldier Fly (Hermetia illucens) Larvae and Propolis as Feed Supplement
}

\author{
Ida Kinasih ${ }^{1}$, Risda Arba Ulfa ${ }^{2}$, Dini Suciawaty ${ }^{3}$, Ramadhani Eka Putra ${ }^{4}$ \\ \{idakinasih@uinsgd.ac.id ${ }^{1}$, risdaarbaulfa@uinsgd.ac.id ${ }^{2}$, dinisuciawaty28@gmail.com³ \\ ramadhani@sith.itb.ac.id $\left.{ }^{4}\right\}$ \\ Department of Biology, Faculty of Science and Technology, Universitas Islam Negeri Sunan Gunung \\ Djati Bandung ${ }^{1,2,3}$, School of Life Sciences and Technology, Institut Teknologi Bandung ${ }^{4}$
}

\begin{abstract}
Broiller chicken (Gallus domesticus) is one of main protein source for Indonesian. In order to produce high quality chicken, it necessary to provide them with affordable high quality diet. Larvae of black soldier fly (Hermetia illucens) showed high potency as alternative protein source for feedstock while propolis had antibiotic and antioxidant properties that may improve the condition of the gut. The purpose of this study was to observe the growth performance and intestinal condition due to application of black soldier fly larvae (BSFL) and propolis as feed supplement. Thirty two broiler chickens (14 days old) were randomly divided into 4 groups each feed with specific feedstock type, P0 (100\% control diet and $1 \mathrm{ml}$ aquadest), P1 (100\% control diet and 1 $\mathrm{ml}$ propolis extract $3 \%)$, P2 (85\% control diet and $15 \%$ BSFL powder +1 ml aquadest), and P3 (85\% control diet and 15\% BSFL powder $+1 \mathrm{ml}$ propolis extract 3\%), for 14 days. Chicken of P2 group showed the highest body weight $(1047 \pm 33.8 \mathrm{~g})$ and the lowest was P3 group $(989.2 \pm 32.5 \mathrm{~g})$. chicken received part of BSF as diet developed slightly bigger area of duodenum and slightly smaller area of jejenum and illeum although not significant.
\end{abstract}

Keywords: Broiler chicken, H. illucens, Intestine, Propolis.

\section{Introduction}

Domesticated animals have been a major protein source for human. Among them, poultry product is considered as the most consumed animal product. Similar pattern also found in Indonesia as both egg and chicken meat are the most consumed animal product. However, the level of production of local poultry industries relatively low compared to market demand. One of the governing factors to produce large numbers of chicken is the availability of affordable feed. In order to produce marketable chicken, a feedstock with high level protein is required. The protein sources for commercial chicken feed in Indonesia is depend on fish mill and other protein sources (such as soyben meal) which mostly acquired by import, a crucial factor that induced a high feedstock price which in the end increased the production cost and lowered the level of production. Because of that, it is necessary to find replacement of imported component of feed substance, which fullfill the nutrient requirement of chicken while followed the law of Islam, which could produce locally. One alternative which have been suggested as alternative of protein (the main imported component of feed) is insect, such as black soldier fly (BSF) (Hermetia illucens) [1][2][3][4][5][6][7][8]. This insect is relatively easy and cheap to produce as they fed on organic wastes which is produced in huge numbers 
through human economic activities [9]. In Indonesia, BSF industry in various level of production already developed. However, the level of production still in early stage in which may not able to fully supply complete feed stock replacement for local broiler chicken while local chicken farmers still unconvince to fully BSF larvae application for feed replacement.

Unlike fish meal and soybean mean, studies showed that BSF larvae contain chitin, one of the substance which relatively indigestible by animals [10][11]. This substance could modulates gut microbiota and short chain fatty acids production [11] and probably alter some gut anatomy. On the other hand, change in diet may produces some physiological shock to chicken such as lower resistance to disease and degenerative liver [12]. Application of natural remedy, like propolis, may counter these effect [13][14].

Based on previous facts, the aim of the present study was to evaluate fully and partly application of BSF larvae, with and without addition of propolis, as potential feed for broiler chicken diet. To assess the potency, we measured the effect of the application on bodyweight, feed intake, feed conversion ratio, and intestinal tissues condition.

\section{Material and methods}

\subsection{Black soldier fly larvae}

Eggs of black soldier fly colonies kept in Laboratory of Animal Physiology, UIN Bandung were hatched to obtain the larvae (furtherly will be state as BSFL in this manuscript). BSFL were fed on commercial chicken feed mixed with distilled water ( $60 \%$ of weight) and kept at relatively constant environment condition $\left( \pm 28^{\circ} \mathrm{C}\right.$ and $70 \%$ relative humidity). All larvae were kept for 14 days, harvested, and dried at oven $\left(60^{\circ} \mathrm{C}\right)$ for 24 hours. Dried larvae then milled to produced BSFL powder.

\subsection{Application}

Fourty one-day-old male boiler chickens (Ross 308) were reared from day 1 to day 21 and feed with commercial diet. After 21 days, chick were separated randomly allotted to 4 dietary treatments for two weeks. The treatments consisted of:

P0: Chicks fed on $100 \%$ commercial diet and $1 \mathrm{ml}$ aquadest was administrated through oral feeding (control).

P1: Chicks fed on $100 \%$ commercial diet and $1 \mathrm{ml}$ of $3 \%$ propolis was administrated through oral feeding (control).

P2: Chicks fed on $85 \%$ commercial diet mixed with $15 \%$ BSFL powder and $1 \mathrm{ml}$ aquadest was administrated through oral feeding (control)

P3: Chicks fed on $85 \%$ commercial diet mixed with $15 \%$ BSFL powder and $1 \mathrm{ml}$ of $3 \%$ propolis was administrated through oral feeding (control).

The growth performance parameters measured were bodyweight, feed intake (FI) and feed convertion ratio (FCR). Body weight was recorded everday until day 35. During body weight measurement the physical condition of the chicks were observed to find the sick chicks. Feed intake (FI) was calculated as feed given minus refusal feed. Feed conversion ratio (FCR) was calculated as bodyweight-gain/feed intake [15].

\subsection{Intestinal analysis}

At 35 days of age, 24 chickens (six chickens from each feeding group) were chosen randomly. The chickens were slaughtered and eviccerated carcasses were obtained and the head, neck, feet and abdominal fat were removed to obtain the chilled carcas. The intestine 
duodenum, jejenum and illeum weights and long were immediately recorded, then fixed in $10 \%$ neutralized formalin for further processed. The tissues were the dehydrated with increasing concentrations of ethyl alcohol $(70 \%, 90 \%, 96 \%$ and $100 \%)$, then washed in xylenne then embedded in paraffin. The paraffin blocks were cut using microtome into $6-\mu \mathrm{m}-$ thick discontinous parrafin-embedded section per sample that were stained with hematoxylin and eosin (H\&E).

Height and base widht of the villi and villi crypt depth from each samples were examined under a light microscope (Olympus), while representative fields were photographed and digital images were captured for morphometric analysis using Video Measuring Gauge IV-560 (for Company Limited). Morphometric measurements conducted on villus height (a), crypt depth (b), villus basal width (c) and villus apical width (d). Apparent villus surface area was estimated as $(\mathrm{c}+\mathrm{d}) / \mathrm{d} \times$ a [16].

\subsection{Data analysis}

The differences on growth performance and instestinal morphometry were analyzed by ANOVA. The comparison between the means was performed by Kruskal-Wallis. All statistical analysis were conducted by Paleontological Statistic (PAST) software ver. 3.16 [17].

\section{Result and discussion}

\subsection{Growth}

This study showed highest bodyweight was recorded for group P2 while group P3 showed the lowest bodyweight although the differences were not significant (Table 1). On the other hand both chicken groups fed on commercial feed mixed with BSF showed higher feed intake but lower feed conversion ratio compared to groups fed on commercial diet although statistically insignificant (Table 1).

Table 1. Comparison of Body Weight, Feed Intake and FCR among treatment groups

\begin{tabular}{|c|c|c|c|c|c|}
\hline \multirow{2}{*}{ Variables } & \multicolumn{4}{|c|}{ Treatments } & \multirow{2}{*}{$\begin{array}{c}\text { Significance } \\
\text { level }\end{array}$} \\
\hline & P0 & P1 & $\mathbf{P 2}$ & P3 & \\
\hline $\begin{array}{l}\text { Body weight } \\
\text { (gr/individu) }\end{array}$ & $1010 \pm 44.8$ & $1025.8 \pm 25.6$ & $1047.5 \pm 33.8$ & $989.2 \pm 32.5$ & NS \\
\hline $\begin{array}{l}\text { Feed intake } \\
\text { (gr) }\end{array}$ & $3792.5 \pm 628.8$ & $3913.1 \pm 652.2$ & $4433.3 \pm 738.9$ & $4280 \pm 713.4$ & NS \\
\hline $\begin{array}{l}\text { Feed } \\
\text { Conversion } \\
\text { Ration (FCR) }\end{array}$ & $1.2 \pm 0.2$ & $1.1 \pm 0.1$ & $1.0 \pm 0.1$ & $0.9 \pm 0.1$ & NS \\
\hline
\end{tabular}

NS: not significant difference (p.>0.05)

The insignificant effect of propolis to body weight also reported by Acikgoz [18]. Interestingly, when both BSF and propolis added to diet, the chicken experienced lowest body weight even though their feed intake was higher than control group. It seem there are antagonist effect of propolis on the chicken that consumed relatively indigestible substance, a further study is need for this. On the other hand, increasing body weight of chicken fed on commercial feed combined with propolis also reported by Hascik [19] and Hassan [20]. On 
the other hand, increasing body weight on chicken that consumed BSF, but not significant, also reported by Kawasaki et al. [21].

The growth pattern of chicken relatively similar among all groups but P2. Chicken of P2 showed slower weight gain at early stage and significantly gain weight at later stage (Fig. 1). High content of indigestible chitin may prevent the early stage larvae to obtain enough nutrient for body weight gain although combining BSF and propolis produced similar growth pattern to control group. Further studies are required for better understanding on the role of propolis in digestibility of indigestible carbohydrate.

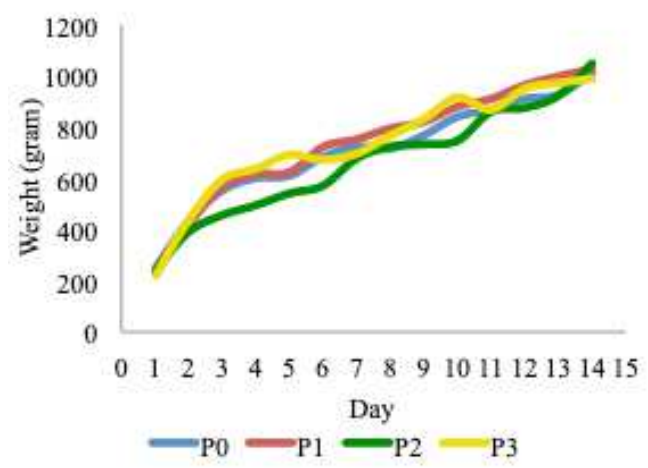

Fig. 1. Growth pattern and average weight of carcas

\subsection{Intestinal analysis}

This study showed application BSF as part of diet of produced higher villus of jenenum and shorter duodenum and illeum (Table 2). On the other hand, chickens which received diet of combination between commerial feed and propolis showed lowest villus height of all doudenum, jejenum, and illeum (Table 2).

Table 2. Comparison of Villus Height

\begin{tabular}{lccccc}
\hline \multirow{2}{*}{ Variables } & \multicolumn{4}{c}{ Villus height $(\boldsymbol{\mu m})$} & $\begin{array}{c}\text { Significance } \\
\text { level }\end{array}$ \\
\cline { 2 - 6 } & P0 & P1 & P2 & P3 & NS \\
Duodenum & $539.46 \pm 119.16$ & $393.22 \pm 57.79$ & $417.85 \pm 108.54$ & $428.69 \pm 139.50$ & NS \\
Jejenum & $448.90 \pm 125.01$ & $465.04 \pm 58.93$ & $475.13 \pm 101.92$ & $478.42 \pm 97.03$ & NS \\
Illeum & $523.27 \pm 142.23$ & $421.88 \pm 79.23$ & $453.66 \pm 66.40$ & $455.74 \pm 176.56$ & \\
\hline
\end{tabular}

NS: not significant difference ( $\mathrm{p} .>0.05$ )

Shorter or lower intestinal villi found in this study is consistent with the result of Eyng et al. [22]. On the other hand study by Tekeli et al. [23] and Parakur et al. [24] showed higher and wider intestinal villi of the chicken feed with propolis compared to control group.

Studies showed that villi height related to greater nutrient absorption [25][26][27] and feeding on indigestible carbohydrate may increases the villus height [28]. However, in this study there were no significant difference on the villus height among all test groups as also reported by Kawasaki et al. [21].

Chicken received propolis as feed suplement showed the lowest height of duodenum which may related to the lower carbohydrate digestion in duodenum. Studies showed that 
propolis has an antihyperglycaemic effect and inhibites carbohydrate digestion into monosaccharides thus lowering the function of duodenum for absorption [29][30]. This condition may explained higher feed intake by chicken fed on control diet and administrated with propolis than control group as compensation for lower monosaccharides absorption.

On the other hand, chicken received part of BSF as diet developed slightly bigger area of duodenum and slightly smaller area of jejenum and illeum although not significant (Fig 2 and 3). This result in agreement in previous finding of Cutrignelli et al. [5] and Dabbou et al. [31].

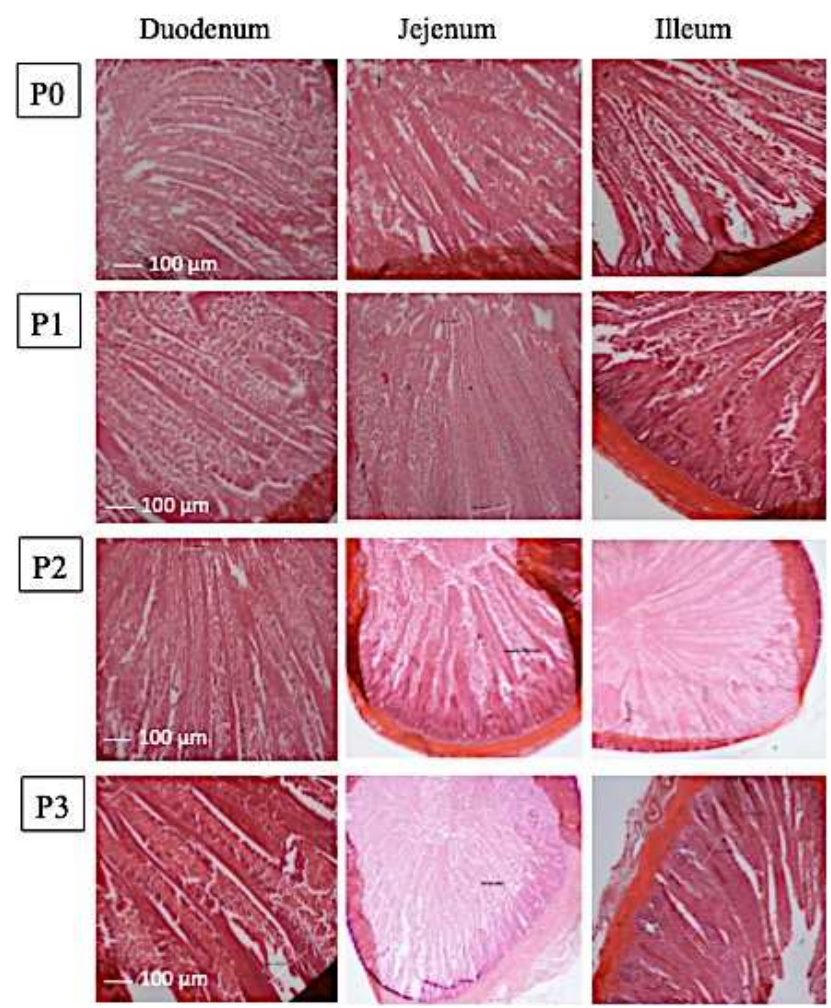

Fig. 2. Histology of duonenum, jejenum and illeum for each treatment
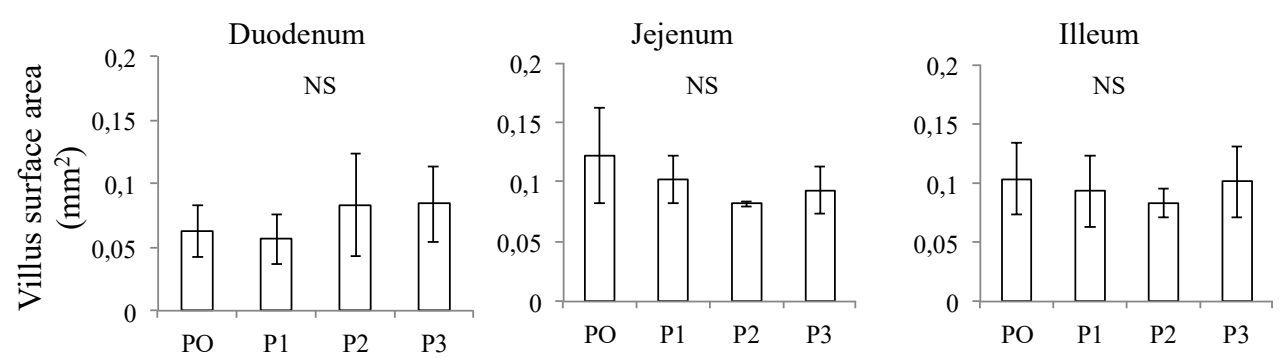

Fig. 3. Comparison of villus surface area among chicken groups received different types of diet

Smaller and shorter area indicated reduced area for nutrition absorption [25] and a decreased villi function [32]. This explained the lower feed conversion rate due to reduced 
digestibility which may related to high chitin content which may reduce the digestibility of nutrient especially crude protein [33] [34].

\section{Conclusion}

BSF and propolis can be apply as potential replacement of part of the basal feed of local broiler chicken if applied separately. Further studies are required to provide better understanding on the digestibility of BSF larvae on broiler chicken especially on the effect of chitin to digestibility and the antagonist effect of propolis to it digestibility on birds.

\section{Acknowledgements}

This study was partially supported by DIPA BOPTN UIN Sunan Gunung Djati Bandung recieved by first author and PTUPT grant received by last author.

\section{References}

[1] H. P. S. Makkar, G. Tran, V. Heuzé, and P. Ankers, "State-of-the-art on use of insects as animal feed," Animal Feed Science and Technology. 2014, doi: 10.1016/j.anifeedsci.2014.07.008.

[2] M. De Marco et al., "Nutritional value of two insect larval meals (Tenebrio molitor and Hermetia illucens) for broiler chickens: Apparent nutrient digestibility, apparent ileal amino acid digestibility and apparent metabolizable energy," Anim. Feed Sci. Technol., 2015, doi: 10.1016/j.anifeedsci.2015.08.006.

[3] V. Maurer et al., "Replacement of soybean cake by Hermetia illucens meal in diets for layers," J. Insects as Food Feed, 2016, doi: 10.3920/JIFF2015.0071.

[4] A. Schiavone et al., "Nutritional value of a partially defatted and a highly defatted black soldier fly larvae (Hermetia illucens L.) meal for broiler chickens: Apparent nutrient digestibility, apparent metabolizable energy and apparent ileal amino acid digestibility," J. Anim. Sci. Biotechnol., 2017, doi: 10.1186/s40104-017-0181-5.

[5] M. I. Cutrignelli et al., "Evaluation of an insect meal of the Black Soldier Fly (Hermetia illucens) as soybean substitute: Intestinal morphometry, enzymatic and microbial activity in laying hens," Res. Vet. Sci., 2018, doi: 10.1016/j.rvsc.2017.12.020.

[6] I. Kinasih et al., "Addition of Black Soldier Fly Larvae (Hermetia illucens L.) and Propolis to Broiler Chicken Performance," in IOP Conference Series: Earth and Environmental Science, 2018, doi: 10.1088/1755-1315/187/1/012026.

[7] A. Schiavone et al., "Black soldier fly larva fat inclusion in finisher broiler chicken diet as an alternative fat source," Animal, 2018, doi: 10.1017/S1751731117003743.

[8] A. Schiavone et al., "Black soldier fly defatted meal as a dietary protein source for broiler chickens: Effects on carcass traits, breast meat quality and safety," Animal, 2019, doi: 10.1017/S1751731119000685.

[9] Y.-S. Wang and M. Shelomi, "Review of Black Soldier Fly (Hermetia illucens) as 
Animal Feed and Human Food," Foods, 2017, doi: 10.3390/foods6100091.

[10] A. Waśko, P. Bulak, M. Polak-Berecka, K. Nowak, C. Polakowski, and A. Bieganowski, "The first report of the physicochemical structure of chitin isolated from Hermetia illucens," Int. J. Biol. Macromol., 2016, doi: 10.1016/j.ijbiomac.2016.07.038.

[11] L. Borrelli et al., "Insect-based diet, a promising nutritional source, modulates gut microbiota composition and SCFAs production in laying hens," Sci. Rep., 2017, doi: 10.1038/s41598-017-16560-6.

[12] D. Cîrnatu, A. Jompan, A. I. Sin, and C. A. Zugravu, "Multiple organ histopathological changes in broiler chickens fed on genetically modified organism," Rom. J. Morphol. Embryol., 2011.

[13] H. R. Taheri, H. R. Rahmani, and J. Pourreza, "Humoral immunity of broilers is affected by oil extracted propolis (OEP) in the diet," Int. J. Poult. Sci., 2005, doi: 10.3923/ijps.2005.414.417.

[14] I. Klaric, M. Pavic, I. Miskulin, V. Blazicevic, A. Dumic, and M. Miskulin, "Influence of dietary supplementation of propolis and bee pollen on liver pathology in broiler chickens," Animals, 2018, doi: 10.3390/ani8040054.

[15] Z. Kamran et al., "Effect of low-protein diets having constant energy-to-protein ratio on performance and carcass characteristics of broiler chickens from one to thirty-five days of age," Poult. Sci., 2008, doi: 10.3382/ps.2007-00180.

[16] P. A. Iji, R. J. Hughes, M. Choct, and D. R. Tivey, "Intestinal Structure and Function of Broiler Chickens on Wheat-Based Diets Supplemented with a Microbial Enzyme," Asian-Australasian J. Anim. Sci., 2001, doi: 10.5713/ajas.2001.54.

[17] O. Hammer-Muntz, D. Harper, and P. Ryan, "PAST-palaeontological statistics, ver. 1.89," Palaeontol. Electron., 2001.

[18] Z. Açikgöz, B. Yücel, and Ö. Altan, "The effects of propolis supplementation on broiler performance and feed digestibility," Arch. fur Geflugelkd., 2005.

[19] P. HAŠČÍK*, M. , Miroslav KROČKO, Jozef GARLÍK, Ibrahim ELIMAM, KAČÁNIOVÁ, Marek BOBKO, Henrieta ARPÁŠOVÁ, Klára VAVRIŠINOVÁ, and O. BUČKO, "The effect of propolis extract in the diet of chickens Ross 308 on their performance," J. Cent. Eur. Agric., vol. 15, no. 4, pp. 133-146, 2014.

[20] H. Y. A. E. Rasha I.M. Hassan, Gamal M.M. Mosaad, "Effect of Feeding Propolis on Growth Performance of Broilers," J. Adv. Vet. Res., vol. 8, no. 3, pp. 66-72, 2018.

[21] K. Kawasaki et al., "Evaluation of black soldier fly (Hermetia illucens) larvae and pre-pupae raised on household organic waste, as potential ingredients for poultry feed," Animals, 2019, doi: 10.3390/ani9030098.

[22] C. Eyng, A. E. Murakami, C. R. A. Duarte, and T. C. Santos, "Effect of dietary supplementation with an ethanolic extract of propolis on broiler intestinal morphology and digestive enzyme activity," J. Anim. Physiol. Anim. Nutr. (Berl)., 2014, doi: 10.1111/jpn.12116.

[23] A. Tekeli, H. R. Kutlu, L. Celik, and F. Doran, "Determination of the effects of z. officinale and propolis extracts on intestinal microbiology and histological characteristics in broilers," Int. J. Poult. Sci., 2010, doi: 10.3923/ijps.2010.898.906.

[24] I. Prakatur et al., "Intestinal morphology in broiler chickens supplemented with propolis and bee pollen," Animals, 2019, doi: 10.3390/ani9060301.

[25] W. F. Caspary, "Physiology and pathophysiology of intestinal absorption," in American Journal of Clinical Nutrition, 1992, doi: 10.1093/ajcn/55.1.299s.

[26] C. Amat, J. M. Planas, and M. Moretó, "Kinetics of hexose uptake by the small and 
large intestine of the chicken," Am. J. Physiol. - Regul. Integr. Comp. Physiol., 1996, doi: 10.1152/ajpregu.1996.271.4.r1085.

[27] M. Samanya and K. Yamauchi, "Histological alterations of intestinal villi in chickens fed dried Bacillus subtilis var. natto," Comp. Biochem. Physiol. - A Mol. Integr. Physiol., 2002, doi: 10.1016/S1095-6433(02)00121-6.

[28] B. Baurhoo, L. Phillip, and C. A. Ruiz-Feria, "Effects of purified lignin and mannan oligosaccharides on intestinal integrity and microbial populations in the ceca and litter of broiler chickens," Poult. Sci., 2007, doi: 10.1093/ps/86.6.1070.

[29] M. M. Skopec, A. K. Green, and W. H. Karasov, "Flavonoids Have Differential Effects on Glucose Absorption in Rats (Rattus norvegicus) and American Robins (Turdis migratorius)," J. Chem. Ecol., 2010, doi: 10.1007/s10886-010-9747-9.

[30] T. Matsui et al., "Strong antihyperglycemic effects of water-soluble fraction of Brazilian propolis and its bioactive constituent, 3,4,5-tri-O-caffeoylquinic acid," Biol. Pharm. Bull., 2004, doi: 10.1248/bpb.27.1797.

[31] S. Dabbou et al., "Black soldier fly defatted meal as a dietary protein source for broiler chickens: Effects on growth performance, blood traits, gut morphology and histological features," J. Anim. Sci. Biotechnol., 2018, doi: 10.1186/s40104-0180266-9.

[32] D. J. Langhout, J. B. Schutte, P. Van Leeuwen, J. Wiebenga, and S. Tamminga, "Effect of dietary high- and low-methylated citrus pectin on the activity of the ileal microflora and morphology of the small intestinal wall of broiler chicks," Br. Poult. Sci., 1999, doi: 10.1080/00071669987421.

[33] A. Razdan and D. Pettersson, "Effect of chitin and chitosan on nutrient digestibility and plasma lipid concentrations in broiler chickens," Br. J. Nutr., 1994, doi: 10.1079/bjn19940029.

[34] S. M. Hossain and R. Blair, "Chitin utilisation by broilers and its effect on body composition and blood metabolites," Br. Poult. Sci., 2007, doi: 10.1080/00071660601156529. 